\title{
ON THE SIGNIFICANCE OF KARL ERNST VON BAER'S DOCTORAL THESIS ON ESTONIANS' ENDEMIC DISEASES (1814) FOR ESTONIAN ANTHROPOLOGY
}

\author{
JaAn Kasmel, Tiiu Kasmel \\ Centre for Physical Anthropology, University of Tartu, Tartu, Estonia
}

\begin{abstract}
In the second chapter of his first research paper, the doctoral dissertation written in Latin and defended at the University of Tartu (the former Imperial University of Dorpat) in 1814, K.E. von Baer, the future natural scientist of world renown, characterised the body build and mentality of Estonians (men, women and children), in a considerably more detailed way than the previous brief overviews. Therefore, this paper is considered the beginning of research of Estonians from the viewpoint of physical anthropology.

The current overview will deal with the role of Juhan Aul, Professor of Zoology at the University of Tartu, in giving an anthropological assessment to Baer's doctoral thesis.

This is followed by a discussion on whether Baer's thesis belongs to the area of medical topography (geography). Our examination shows that Baer's medical geographical thesis might be called an anthropological medical geographical paper.

Finally, the question is posed whether the material presented in Baer's doctoral thesis on the relations between Estonians' health, well-being, culture, society and environment corresponds to the characteristics of the notion "medical anthropology" that has been in use since 1963, so that it could be considered the beginning of Estonian medical anthropology.
\end{abstract}

Keywords: K.E. von Baer, physical anthropology, medical anthropology, history of anthropology, Estonia 
In the early 1980s, because of certain circumstances, we became interested in dealing with Estonians' physical anthropology, only the anthropology of schoolchildren, and with some problems in the history of Estonian anthropology.

By that time, three major studies had been published or were in the process of publishing by Professor of Zoology Juhan Aul (1897-1994), the founder of Estonian anthropology and systematic anthropological research of Estonians, pioneer of biometry and data analysis, one of our first paleoanthropologists, a well-known zoologist and long-time lecturer of the University of Tartu (then Tartu State University), a versatile researcher and experienced educator [12].

In addition to those mentioned above, he had issued nearly 200 publications, most of them on anthropology, which also included overviews of history of anthropological research in Estonia [11].

To give an idea of the scope of Prof. J. Aul's anthropological work, it should be noted that during his lifetime he personally measured more than 50,000 people of different ages.

He also studied other ethnic groups who lived in in the territory of Estonia and its vicinity, including Izhorians and Votians who have become extinct by now [12].

The first data on the everyday life and descriptions and appraisals of the appearance and body build of one or another nation or inhabitants (men, women, children) of a geographical region can be found in the writings of early travellers and explorers.

The first such characterisations of Estonians date from the works of J.G. Georg, A.W. Hupel and others from the middle of the second half of the 18th century [13].

In the introduction to his Russian-language monograph printed in Tartu in 1964, Estonians' Anthropology, although its 387 pages deal with Estonian men's anthropology only, Prof. Juhan Aul wrote that in that year 150 years had passed from the publication of the first anthropological study of Estonians [13].

This was the doctoral thesis On Estonians' Endemic Diseases written in Latin by Karl Ernst von Baer, a graduate of the Imperial University of Dorpat (the present University of Tartu), and defended on 29 August 1814 (10 September New Style) [4]. Baer was the first to give more detailed descriptions and assessments of Estonians' (men's, women's children's) body build and appearance than before. K.E. von Baer's doctoral thesis was the first step on his long and fruitful path as a scientist, and it also marked the beginning of the physical anthropological research of Estonians. 
Prof. J. Aul's monograph on Estonian men's anthropology was thus dedicated to the 150th anniversary of the defence of K.E. von Baer's doctoral thesis as well as to the beginning of anthropological research of Estonians [13].

Because of the coincidence of several unfavourable circumstances, J. Aul needed more than three decades, to be exact -32 years, for writing this monograph, starting from data collection all over Estonia to the publication of the book [9]. However, he had an excellent opportunity for presenting his monograph at the 7th International Congress of Anthropology and Ethnography in Moscow in August 1964 [10].

By that time, anthropological research in the whole of what was then the Soviet Union had made noticeable progress, particularly in the last few years [14].

In 1977, Prof. J. Aul published Estonian Women's Anthropology [1] and in 1982 Estonian Schoolchildren's Anthropology [2]. The former was published by his 80 th and the latter by his 85 th birthday.

In the three anthropological studies mentioned, J. Aul used:

64 anthropometric characteristics and indices of more than 15,000 Estonian men, aged mostly 22 years;

52 characteristics and indices of more than 1000 Estonian women aged 20-30 years;

36 characteristics and indices of more than 30,000 schoolchildren aged $7-18$ years (14,862 boys and 15,195 girls).

The descriptive characteristics he assessed were the eye and hair colour of Estonian men, women and schoolchildren, nose profile of men and women, and development of schoolgirls' breasts [12].

Based on his anthropological experience and knowledge, J. Aul decided that K.E. von Baer's doctoral thesis On Estonians' Endemic Diseases could be considered the first profound study on Estonians' anthropology, and it could be regarded the beginning of physical anthropological research of Estonians.

Relatively little has been written about Baer's doctoral thesis as a medicalgeographical study. The main reasons seem to be the local character of the theme, treatment of a geographically limited area and the fact that the thesis was written in Latin [6].

From the anthropological point of view, $\$ 14$ of the second chapter of Baer's Latin doctoral thesis ("On Estonians' customs") is of particular interest, as it describes Estonians' body build and mentality.

His short description in Latin of Estonians' habitus (body build) is a characteristic example of the anthropological thought of his period [13].

Below we publish the full text of $\$ 14$ of the second chapter of the thesis in English to enable researchers to get an easier overview of the problems mentioned [3]. 


\section{Chapter II \\ On Estonians' customs}

\section{$\$ 14$ \\ Body build and mentality}

Even for a sharp-witted observer, nearly nothing is more difficult than to describe the body build and temperament of a nation in general. Even if its way of action and mentality are well known to him; even if he has lived among this nation for many years and has paid attention to its physical condition, it proves extremely difficult to distinguish from among innumerable individual observations those which are generally correct, and to present only the essential part in such a way that even a foreigner would understand by which the described nation differs from others. Therefore, it happens that we often see very different descriptions about some nation and often notice downright contradictory things in the description of the same observer.

The body of Estonians is juicy rather than dry, and their muscles, considering the nature of the climate, would definitely be more flaccid if not the hard work and lack of all comforts had not hardened them. Most Estonians are of medium stature; the face is usually quite sturdy, dull, without noticeable features and pale; only if they work in the hot sun, the face reddens. Hair is most often blond, in childhood often white; black hair and swarthy complexion also occur. The bodily strength is rather medium; the temperament is generally phlegmatic with a slight tendency to melancholic. Therefore, their body is not particularly receptive to diseases, and their spirit only seldom loses its usual disposition. The gait is faltering and all movements slow. - Only very few Estonians are melancholics in the strict sense - those about whom I just noted that they stand out by their black hair. Those are, by the way, of small stature but with a firmer and stronger body build. They are also more serious, obstinate and uncommunicative than the phlegmatic majority. While the face of the latter expresses dull-witted numbness, the melancholics' look shows hidden indignation. By the way, there is a great difference between the Estonians living in the northern part of the country and in the vicinity of Tartu. The latter surpass the former in their growth and they have a candid appearance because their facial features that are more easily understandable than those of their compatriots living around Tallinn; they do not have so sturdy faces; they are somewhat more prone to action, less slow and more friendly to people of other classes. - Both sexes, however, differ much more from each other. The national character described above can hardly be attributed to Estonian girls. 
They are more lively, quicker, merrier when working and love to sing at work, which the menfolk usually do not do. Their hair is more yellowish than that of men's, and none of them is black-haired. ${ }^{11}$

If we wanted to transfer this to the women around Tartu, some things should be crossed out. By the way, I have found no one here who might consider herself beautiful. The physiologist and the psychologist can easily find the reasons for the differences between the genders. As the woman, particularly before she is encumbered by the worries of the mother of the family, tends towards the sanguine temperament, she is less sensitive to various kinds of hardships; the sense of subjugation which robs the man of all his strength and dignity, means next to nothing to women, considering their constitution.

I would like to add a few words about the moral character of Estonians. Too many writers have attempted to blame all kinds of faults on this nation; thus, Paul Einhorn thinks that this nation is completely devoid of virtue, as the word virtue is claimed to be lacking in their language. Oh, what a laudable argumentation! Of the faults that cannot be denied, I would enumerate here: laziness, dirtiness, excessive humility to the mightier and cruelty and atrociousness to their inferiors. Their tendency to sexual pleasures has often been exaggerated; even such a wonderful man as Hupel seems to have been unfair in this respect.

For a long time, K.E. von Baer's doctoral thesis has been considered a medical geographical study [6], but because of its description of Estonians' body build and appearance, it could also be considered an anthropological, medical and geographical paper.

One of the earliest studies that presents medical-geographical data on the territory of Estonia is A. Bergmann's doctoral thesis De ruricolorum Livoniae... defended in Leipzig in 1762.

In 1797, medical administrations were founded in capitals of provinces of Tsarist Russia. One of their obligations was to send regularly medical topographical descriptions of the province to the Medical Collegium [7].

To explain the terms 'medical topography' and 'medical geography', it should be added that in the case of medical topography landscape features are associated with health indicators. When the notion of topography is broadened, it approaches that of geography; therefore, it can be said that medical

${ }^{1}$ Dr. Petri has seen quite the opposite. During the twelve years he was active in Estonia, he claims to have seen almost only swarthy women. Oh, what a shameless liar! 
geography studies the natural and socio-economic conditions that influence people's health [5].

The Medical Administration of the Estonian province required the necessary data from district doctors. Some manuscript medical topographical descriptions have been preserved in archives to the present time. One of the earliest is the medical topographical overview of Järvamaa County by the Paide district doctor A. Fronau.

The first professors of the Faculty of Medicine at the reopened Imperial University of Dorpat (now Tartu) considered it most necessary that doctors should know the local conditions [7].

In 1795, Daniel Georg Balk (1764-1826), the future Ordinary Professor of Pathology, Semiotics, Therapy and Clinic at the University of Dorpat (Tartu) and scientific supervisor of K.E. v. Baer's doctoral thesis [8], emphasised in his paper "Eine medizinischpolitische Abhandlung" that "climate, way of life, ethnic customs, ethnic constitution change the course and character of diseases and by that also influence the methods of treatment."

In the first decades of the 19th century, the medical scientists of the Imperial University of Dorpat (Tartu) published medical topographical (and geographical) descriptions. Such descriptions as a method of studying sanitary conditions played an essential part in the period of formation of sanitation and hygiene.

K.E. v. Baer's doctoral thesis was the first paper of this kind written at the University of Tartu in that period [7].

A study of the history of anthropology in our neighbouring countries revealed that Lithuanian professors Gintautas Jurgis Česnys (1940-2009) and Salezijus Pavilonis (1919-1998) have written in their articles (1968) that the books, articles and ideas from the University of Vilnius in the early 19th century represented the trend of medical anthropology [15].

Based on that, we attempt to find if the connections between Estonians' health, well-being, culture, society and environment as presented in K.E. v. Baer's doctoral thesis meet the definition of "medical anthropology" as a concept used since 1963.

By Baer's 180th birth anniversary, the Estonian SSR Academy of Sciences and the Estonian Naturalists' Society compiled the collection Folia Baeriana I (Tallinn: Valgus, 1975, 184 pp., 1000 copies) [4].

The Estonian translation of Baer's doctoral dissertation was published on pages 141-181 of this volume. We provide a short summary of it according to chapters and their sections, giving also their page numbers. 
In the preface to his doctoral dissertation (pp. 143-145), Baer promised, in his own words, "to reach the knowledge of the human organism in the states of both health and disease." The preface is followed by five chapters [3].

The first chapter ("Physical geography of Estonia and the part of Livonia inhabited by Estonians", pp. 146-154) consists of eight sections. In these, Baer describes the extent and location $(\$ 1$, p. 146$)$, relief $(\$ 2$, pp. 146-147), hills, rivers and lakes ( $\$ 3$, pp. $147-148)$, the surrounding sea ( $\$ 4$, p. 148$)$, atmosphere ( $\$ 5$, pp. 149-150), physical climate ( $\$ 6$, pp. 150-151), changes in weather according to months (\$7, pp. 151-153) and chorographia (\$8, pp. 153-154) in the region inhabited by Estonians - then the province of Estonia and the northern part of the province of Livonia. He notes that people residing in marshy areas fall ill more frequently, but, under the influence of the predominant miasmatic doctrine, he exaggerates the pathological effect of marsh vapours. In Baer's opinion, the region of Livonia inhabited by Estonians was healthier for living, and he also refers to mineral springs situated there, which had not been sufficiently studied yet. He also thinks that the cooling of climate in the region at that time was caused by thinning and felling of large forests that protected the area from easterly winds.

The eight sections of the second chapter ("On Estonians' customs", pp. 154164 ) give a general overview of the Estonian people ( $\$ 9$, pp. 154-155), their dwellings ( $\$ 10$, pp. 155-157), clothing ( $\$ 11$, p. 157), food ( $\$ 12$, pp. 157-158) and drink (\$13, p. 159), body build and mentality (\$14, pp. 160-161), hygiene (\$15, pp. 161-163) and way of life in different seasons (\$16, pp. 163-164). Baer refers to the poor dwellings, relatively monotonous vegetarian food and hard working conditions, regarding them as factors conducive to illness - poorly clothed and insufficiently fed peasants had to work regardless of the weather.

The third chapter ("Pathogenic forces", pp. 164-171), which consists of six sections, deals with Estonians' normal health status (\$17, pp. 164-165), the use of steam saunas ( $\$ 18$, pp. 165-167), the general pathological status $(\$ 19$, p. 167), causes of diseases resulting from the characteristics of the soil and the air $(\$ 20$, p. 168), changes in the nature of diseases in different seasons $(\$ 21$, pp. 169-170), diseases resulting from Estonians’ dwellings and food (\$22, pp. 170-171). Baer looked for the causes of diseases not only in natural features but also in the social environment. As his thesis reflects the level of medicine at that time, some of his views on etiology and pathogenesis of diseases are outdated or outright wrong from the viewpoint of present-day medicine. For example, the significance of the soil and the air in the genesis of several diseases has been overrated. Malignant pustule (anthrax) was believed to be caused by moisture; Estonians' habit to spend summer nights in the open air and over- 
eating after harvest in autumn were believed to cause dysentery; intermittent fever (malaria) was believed to be caused by frequent eating of fish. Along with that, Baer was the first to observe that many diseases were more frequent in the northern and eastern districts of Dorpat (now Tartu), which are situated lower and suffered from floods in spring than in the districts with a higher location. Differently from some other authors of the period, Baer considered the sauna generally useful from the physiological and prophylactic point of view. He notes that Estonians consider the sauna a remedy for most diseases. He also expressed the opinion that Estonians are more receptive to chronic diseases.

The eight sections of the second chapter ("On Estonians' customs", pp. 154$164)$ give an overview of the Estonian people generally ( $\$ 9, \mathrm{pp} .154-155)$, the dwellings (\$10, pp. 155-157), clothing (\$11, p. 157), food (\$12, pp. 157-158), clothing $(\$ 13$, p. 159$)$, body build and mentality (\$14, pp. 160-161), hygiene (\$15, pp. 161-163) and way of life in different seasons (\$16, pp. 163-164). Baer refers to the poor dwellings, relatively monotonous vegetarian food and hard working conditions, regarding them as factors conducive to illness - poorly clothed and insufficiently fed peasants had to work regardless of the weather.

The fourth chapter ("Estonians' nosology", pp. 171-176) consists of three sections. Its beginning discusses the difficulties in diagnosing and treatment of frequent diseases of Estonians ( $\$ 23$, pp. 171-172). Baer also presents interesting facts on Estonians' opinions about diseases and their knowledge of anatomy. Thereafter, Baer provides an overview of Estonians' most frequent internal diseases ( $\$ 24$, pp. 172-175). He begins the list with fever diseases (intermittent, purulent, lymphatic, catarrhal and nervous fever); thereafter, he describes rheumatic diseases, inflammations in various parts of the body, acute eruptions (scarlet fever, smallpox and measles), dysentery, dermatological and venereal diseases, intestinal parasites, colics of various kinds, oedemas. Baer notes, however, that cramps and psychic diseases are quite rare among Estonians. Among all the diseases that endangered Estonians, he considered malignant pustule particularly characteristic of this people. He observed that Germans did not suffer from this disease, and Estonians serving at manors had it much less frequently than peasants did. One of the causes for the frequent incidence of this disease was, in his opinion, peasants' poor living conditions. Karl Friedrich Burdach (1776-1847), however, who served as professor of anatomy, physiology and forensic medicine at the University of Tartu (then the Imperial University of Dorpat) from 1811-1814, was already of the opinion that anthrax is transmitted through contact with animals who had died of that disease [6]. Among external or so-called surgical diseases (\$25, pp. 175-176), Baer mentions chilblains, ulcers of all kinds, boils, abscesses, furuncles and 
frequent ophthalmologic diseases. About the latter, he has added that out of the 26 Estonians who visited the clinic of the Imperial University of Dorpat in September 1809, 16 were suffering from ophthalmologic diseases. Baer considers this number very high and thinks that very few countries have as many ophthalmologic patients as Estonia and Livonia. The main reasons for ophthalmologic diseases, in his opinion, were chimneyless houses and peasants' poor personal hygiene.

The last chapter (“On treatment of Estonians' diseases", pp. 176-180) consists of two sections: the first describes medical aid Estonians mostly used at that time (\$26, pp. 177-178); the second formulates the general rules according to which Estonians' diseases had to be treated (\$27, pp. 178-180). Here, K.E. von Baer refers to the scarcity of doctors who would treat peasants, the almost complete lack of hospitals in rural areas and shortcomings in vaccination against smallpox. He also presents data on Estonian folk medicine, on folk healers, their treatment methods, and local medicinal plants. Baer made several proposals for improving peasants' health and sanitary conditions. He sees a solution in improving Estonians' living conditions, building better dwellings for them, founding of hospitals, employing trained midwives and providing wholesome food for the sick. Baer also suggests that peasants should get more meat to eat, particularly in spring when the weather is damp.

At the end of his doctoral dissertation (pp. 180-181), Baer lists the books he studied while working on it and presents eight propositions (p. 181).

To end the current overview, we can see that the five chapters of K.E. v. Baer's thesis deal with the physical geography of Estonians' settlement area (soil, climate and the influence of its cooling, etc.); an outline is given of Estonians' lifestyle, hygiene, way of life in different seasons; some factors conducive to morbidity are mentioned; causes of diseases (natural and social factors) are discussed.

Finally, he makes some proposals for improving the life of Estonian peasants and their medical and sanitary conditions.

Thus, the thesis presents the connections between Estonians' health, wellbeing, culture, society and environment, and thus meets the requirements of the definition of "medical anthropology" as it has been used since 1963.

Therefore, we might say that K.E. von Baer's doctoral thesis from 1814 marks the beginning of Estonian medical anthropology. 


\section{REFERENCES}

1. Aul J. (1977). Eesti naiste antropoloogia. In: Tartu Riikliku Ülikooli Toimetised. Vihik 438. Tartu, 5-103.

2. Aul J. (1982), Eesti kooliõpilaste antropoloogia. Tallinn, Valgus.

3. Baer K.E. (1975), Eestlaste endeemilistest haigustest. Ladina keelest tõlkinud Ü. Torpats. In: Folia Baeriana I. Tallinn, Valgus, 141-181.

4. Ilomets T. (1975). Karl Ernst v. Baeri doktoritöö kaitsmisest. In: Folia Baeriana I. Tallinn, Valgus, 110-112.

5. Kalling K. (2014). Kommentaarid K.E. v. Baeri doktoritööle (tähistamaks 200 aasta täitumist selle kaitsmisest). Eesti Arst, 93(4), 237-240.

6. Kalnin V. (1967). C.E. Baeri doktoriväitekirjast. Nõukogu Eesti Tervishoid, 3, 228-229.

7. Kalnin V. (1973). Meditsiinigeograafia Tartu Ülikooli teadlaste töödes. Eesti Loodus, 10, 583-589.

8. Kalnin V. (1976). Ääremärkusi ja selgitusi K.E. v. Baeri doktoriväitekirja juurde. In: Loomingu Raamatukogu nr 33(977), 59-62,

9. Kasmel J., Kasmel T. (2014). The year 1964 in the history of Estonian anthropology. Papers on Anthropology, XXIII/2, 9-22.

10. Muljeid VII rahvusvaheliselt antropoloogia ja etnograafia kongressilt. (1964). Keel ja Kirjandus, 11, 697-698.

11. Professor Juhan Aul. Kirjanduse nimestik 1919-1997. (1997). Koostanud Sirje Mikelsaar. Tartu, 7-14.

12. Põldvere K. (1997). Juhan Auli elust ja tegevusest. In: Professor Juhan Aul. Kirjanduse nimestik 1919-1997. Koostanud Sirje Mikelsaar. Tartu, 7-14.

13. Ауль Ю. (1964). Антропология эстонцев. (Anthropologia estonica). Tartu Riikliku Ülikooli Toimetised. Vihik 158. Тарту.

14. Международные встречи антропологов в Москве. (1965). Вопросы антропологии, 19, 3-7.

15. Чеснис Г., Павилонис С. (1968). Очерк истории антропологии в Литве. In: Материалы к конференции по истории естествознания в Прибалтике май 1968 г. Вильнюс, 180-185.

\section{Address for correspondence:}

Jaan Kasmel

Centre for Physical Anthropology

Struve 2, Tartu, 51003, Estonia

E-mail: jaanjkasmel@hot.ee 